\title{
THE GOOD PRACTICES IN THE REGULATION OF SOCIAL DEVELOPMENT
}

\author{
Venelin Terziev \\ Academician of the Russian Academy of Natural History, Moscow, Russia, \\ Prof. D.Sc. (Ec.), D.Sc. (National Security), D.Sc. (Social Activities), Ph.D., National Military \\ University, Veliko Tarnovo, Bulgaria; University of Rousse, Rousse, Bulgaria, terziev@skmat.com

\begin{abstract}
In Bulgaria, there is a special interest in foreign experience in all spheres of public life during the transition period, after all, the country is oriented openly and for certain reasons towards international (primarily western) models for functioning and development. The experience of other countries in territorial development regulation is far from indisputable in terms of its undoubted borrowing. Many fragments of this experience are invaluable because they clearly prove the very possibility of a reasonable government policy in terms of the regions.
\end{abstract}

Keywords: good practices, regulation, social development, program, financial support.

\section{INTRODUCTION}

In Bulgaria, there is a special interest in foreign experience in all spheres of public life during the transition period, after all, the country is oriented openly and for certain reasons towards international (primarily western) models for functioning and development. The experience of other countries in territorial development regulation is far from indisputable in terms of its undoubted borrowing. Many fragments of this experience are invaluable because they clearly prove the very possibility of a reasonable government policy in terms of the regions.

The capabilities to regulate the territorial development do not depend on what is, for example the list of local taxes (in one country they are two, in another about a hundred) or what is the state organization (federation, unitary state), but on the socio-economic situation of each country and the nature of the ongoing changes in it. No less important is in what other equal conditions a factor for effective regulation of the territorial development is the degree of compliance of the mechanisms of this regulation with the individual for each country starting conditions and objectives for territorial development and the uniform principles for its regulation. This is namely, what determines in each country with sustainable development the forms of state impact on the regions' potential and the list of regional and local taxes, as well as their amount of income of the respective budgets and the mechanisms for budgetary "equalization" and many others.

\section{GOOD PRACTICES IN THE REGULATION OF SOCIAL DEVELOPMENT}

Switzerland can be considered as a classic example of a federal state. The three-level system of territorial organization implies the existence of a budget hierarchy. The funds from the budget of the federation are directed to support the army, conduct social policy and provide social needs (these are primarily state 
pension costs and the costs for maintenance of roads and railroads). In the budgets of the cantons, costs for healthcare, education (all universities are cantonal), police and public transport are provided. The social costs - construction, utilities, roads and public transport - are financed by the municipal budgets (Georgiev, 2016; Georgiev, 2017-a).

In 1995, the total amount of the costs of all 26 cantons is 100 billion francs, and the expenditure of the budget of the confederation totals 30-40 billion francs. Therefore, the main part of the funds goes to the regional budgets. As a rule, about $70 \%$ of all taxes go to the cantons and municipalities, and around $30 \%$ - to the federal budget. Besides, the federation receives indirect taxes, while the cantons and the municipalities direct taxes. The taxes paid to the federal budget seem to intersect with the cantonal taxes. There is also a double taxation of the same entities. The tax system of Switzerland has some specifics that distinguish it from other European countries. Above all, this is the tax autonomy of the cantons and the emerging intercantonal competition based on it. The functioning of this system causes quite serious differences in the regional economic and social development.

The differentiation of the incomes of the cantonal (regional) budgets grows sharply already in the 50-60-s. The state policy of „equalization“ by investing in social infrastructure in poorer areas, however, has not been conducted in practice. Swiss government gives priority to the pure market approach to reduce the regional disparities in income. The "equalization" is implemented mainly at the expense of the migration from the poorer areas to the richer. Under the conditions of territorial compactness of Switzerland, this line is fully justified. In recent years, however, the picture changes: a practice of "equalization“ appears through the provision of subsidies to regional budgets. In addition, they are provided depending on the financial situation of the cantons. The particular amounts of the funding are discussed at a meeting of the finance directors of the cantons and then a joint decision is made. At the same time, the number of the population in the canton, the amount of the taxes per person, the other receivables per person, etc. are taken in consideration. Thus, the allocation is made based on a mutual agreement between the representatives of the cantons. Approximately one third of the cantons receive additional funds. These cantons, whose residents pay the highest taxes, receive a larger financial support compared with the cantons, whose residents pay lower taxes. The poorest cantons have higher taxes and receive larger financial support. The redistribution of the tax revenues in a single methodology has led to a significant equalization of the regional differences, although the richer cantons have lost economically (Terziev, Kanev, 2019; Terziev, 2019a-k).

Australia is a highly centralized state. The federal authorities are authorized to use all possible forms of taxation, and the states are forbidden to bring in any sales taxes (and other indirect taxes), as well as taxes on personal income and income of the companies. The federal budget collects about $80 \%$ of all taxes in the country.

In such volumes of centralized tax revenues of the states, the own revenues are not enough to finance the costs set for them. Therefore, at a federal level the system of subsidies to the states is widely used, as a policy of equalization is simultaneously conducted. The amount of the subsidies is determined, based on a firm federal control over the costs of the states.

The centralized deductions of the states are based on a single distribution-equalization formula that aims to meet the needs of all states in such a way that uniform standards for public services to be carried out across the country. If the budgetary needs of a state are amended, compared with other states (e.g. in case of changes in the global prices of certain major exports, policy errors of the state or community, etc.), a special committee on subsidies decides on whether additional state subsidies for equalization of the conditions with other states to be provided, or decides that the state itself should reach equilibrium by measures in its financial policy. Usually, such a subsidy is of one-time character and is calculated, as a rule, so that the receiving state is able to restore its financial balance.

The central government prefers to pay particular attention to the equalization of the regional differences through a single formula for allocation of the subsidies, and solves the specific issues relating to their occurrence by means of "addressed" subsidies. The only region that has been granted permanent and special tax benefits (i.e. special tax regime), is the Northern territory. The central government has even concluded a special budget agreement with this region of the country. Since 1978, the Northern territory has received the status of an autonomous territory and powers on self-realization of costs and collection of taxes have been granted. Pursuant to the Self-government act of the Northern Territory, all its tax revenues, loans and other income are included in the state funds to cover its expenses.

In connection with the high percentage of indigenous population and its particular problems, more substantial financial resources are provided to this territory so that the local population is able to solve its problems. In addition to the general subsidies granted based on this formula, additional funds, special assistance and 
targeted subsidies can also be granted for this territory a year. Each year, the Committee on subsidies considers such requests and recommends appropriate measures.

Australia, despite its federal status, seems rather closer to a unitary state. The highly centralized finances in a strong "policy of equalization" allow to achieve results and to provide unified state services throughout the country. This, however, naturally reduces the responsibility of the authorities of the state in respect to their interest in searching new sources of income and better organization of the economy.

Canada is an example of a highly decentralized federal state, which pays great attention to equalization of the differences between the provinces. Canadian provinces have wide powers on both costs and tax collection. In addition to the funds, collected by the provinces themselves, the government makes special deductions in favor of the provinces with low incomes, so that all provinces have the same level of budgetary resources. Redistribution of personal income by the highly progressive tax system plays an important role in equalization of the inter-regional differences. In such a large country like Canada, decentralization helps to adapt social policy to local needs and at the same time to ensure incomes for the provincial governments that are sufficient to maintain uniform standards of public services on equal levels of taxation.

For the purpose of inter-regional equalization, the total federal fund from tax revenues in Canada is divided among the provinces based on a special formula, composed in such a way that all provinces receive equivalent, not less than the average tax calculated on the average taxes in the country. The basic algorithm for calculating the transfers looks like this: At first, the country's average level of taxation is determined (by dividing the sum of tax revenues from all provinces into their total tax base). This indicator (average rate of taxes) is multiplied by the tax base of each province, thus determining the normatively-estimated level of tax receipts per person for the particular province. Then the average sum of taxes per person is determined for the country (at an average per person database for the province and an average national tax rate). The difference between the arbitrary average level of tax revenues per person for the country and the normatively-estimated one for a province is multiplied by the number of the province's population, giving the necessary amount of the transfer (Terziev, 2018-d).

These calculations are made for each type of tax for each province. Recently, the described mechanism for budgetary allocation of resources based on a high degree of autonomy of the provinces, has turned into a subject of sharp political discussions. The idea that a rejection of the policy on uniform delegating of powers to the provinces is necessary, is widely discussed, in order to conduct regional policy that is consistent with their conditions, in favor of special budget regimes for the different regions.

India is an example of a centralized federal state, which seeks to solve a wide range of regional problems by means of a reallocation of the budgetary resources, based both on a single formula and on current address maintenance of specific regions. The huge country with significant regional differences in economic development and income level faces the task to reduce these differences and simultaneously to meet the specific requirements of individual regions.

The subsidies from the federal budget play an important role in filling up the income of the states and eliminating the deficit of funds for implementation of the budget functions assigned to the state. The budgetary system of India provides for the management of budgetary subsidies by creating special committees to consider the various aspects of the budget of the states and local authorities.

In India, there are three types of deductions from the center in favor of the states. In the first place, deductions to assist the states in covering their normal operating costs are provided. They are provided by a recommendation of a "finance committee" - an established by law financial authority, appointed by the central government and called together at least once in every five years. In the second place - "planning deductions" have been established to finance the capital investments and development projects. The decisions on them are made by a planning committee, appointed by the central government. The "planned deductions" are distributed among the states in the so-called "Gadgil formula", which accounts for a wide range of territorial factors and other grounds for allocation of funds. In the third place - there are also "other deductions" - centralized funds, which are provided to the states to fund "socially appropriate" projects (according to the criteria of the center).

In India, in the creation of the system of budgetary relations between the different levels of authority, the requirements of the regions have been carefully taken in consideration. The central government has developed a scheme for the distribution of various types of taxes, share distribution of tax revenues and subsidies based on formulas, equalizing the various regional differences and allowing for free solving of regional problems by the center or meeting of specific requirements at a regional level. Although the scale in which India uses the federal transfers at different government levels has repeatedly stimulated facts about fiscal irresponsibility, the very idea of such deductions is of interest. India uses a combined system for an 
open redistribution, based on uniform formulas and recalculation of a more selective (address) character. At the same time, it tries to take into account specific problems of the regions in the structure of the general formulas. Besides, the Committee on subsidies has also included in the formula special components for "undeveloped" regions (defined by the center), as well as "special states" (e.g. the politically unstable state of Punjab). The problems are openly solved and the budget system is not a subject of endless political negotiations.

The USA is a paradoxical example of stability of the budgetary - tax relations of the state and the regions, as if in the complete absence of constitutional prerequisites for this. Indeed, the US Constitution, adopted more than 200 years ago, does not regulate directly the budgetary - tax relations in the federation. It, however, has solved the main issue for such relationships related to the nature and ways of distribution of powers between the different levels of government. The constitutional convention from 1789 has framed and legally regulated the procedures for distinction between the features of power, which are basically also valid today.

Typical for the American model of "budgetary federalism" is that the states have the same rights in the tax field, as the federation as a whole. Therefore, the states have the same type of taxes as the collected in the federal budget as well. Moreover, the right to determine the amount of these taxes is given to the states themselves. The most significant restriction on the taxing rights of the states is the ban to impose powerful indirect taxes, such as sales tax or VAT. These taxes are considered as impeding the free trade between the states, which is prohibited by the US Constitution.

At the same time, the structure for the allocation of fiscal powers, giving considerable powers of the federal authorities, which has been developed in many years, has led to the general practice of funding of state and local development by them. At the expense of the federal subsidies, a huge number of guidelines for socioeconomic development at a state level is financed, including construction of projects of infrastructure, healthcare, development of forestry, etc (Terziev, 2018-d).

The system for subsidizing the regional development has undergone numerous changes for the last half century, as a result of the permanent prevalence of contradictory trends of centralization and decentralization of the budgetary- tax system. Currently, the federal funds are provided to the states in the form of targeted, block and program grants. Dozens of federal authorities deal with the issues on their granting. Their distribution is conducted under the control of committees and sub-committees of the US Congress. Controversial issues are considered by the federal courts. The federal ministries and departments negotiate the terms for use of the funds, establish procedures for implementation of programs, and identify the sections of the budget assignments, paragraphs and costs. The federal authorities monitor the course of use of the funds and require accurate accounts by the states. A controller-auditor of the US Congress also monitors the spending of the funds allocated to the states.

In the process of decision making in relation to financial equalization, a variety of models based on formulation estimates of the quantities, equalizing the subsidies, are used. Some of the received funds under them are allocated by the federal governments to the states between the cities and counties, taking into account the number of population, tax revenues and income per capita.

Germany. The problem of income distribution between the two federal levels - the federation and the provinces, is very topical in Germany. The "financial equalization" between the federation and the provinces in the broad sense of the word represents by itself providing the different levels with budget funds, which do not have targeted nature. Moreover, under certain conditions, the federation provides the provinces with target payments - for example for the implementation of such common projects as improving the regional infrastructure, solving agricultural problems, expanding the construction of higher education institutions, supporting research. The specified target investments are also implemented in accordance with the laws on cash payments, financed by the federal budget (e.g. housing assistance, assistance for childcare and education of a child, education assistance) and as financial assistance, for stimulation of urban development, social housing and public transport development. The constitution justifies these exemptions with the need of financial participation of the federation in the tasks of the provinces.

The target payments from the federal budget affect the allocation of financial resources between the federation and the provinces, but not within the provinces. These payments carried out by the federation and the provinces with different intensity, distinguish from the system of financial equalization, which is conductive for equalization of the income differences between the different budget levels.

The provision of the corresponding budgetary resources to each level is carried out by allocating tax revenues in two directions - between the federation and the provinces, and partially the municipalities (vertical financial equalization) and within the provinces (horizontal financial equalization). The legislation provides for a number of corrective tools in the field of vertical financial equalization: 
- Equalization of the excessive workload. If, in accordance with the federal law in the province, additional costs are assigned or part of the revenue is taken, and these costs are limited by a certain period of time, then instead of changes in the share of the federation and the provinces in VAT, financial subsidies from the federal funds can be granted;

- Compensation for specific costs associated with the creation of special institutions in the provinces or municipalities at the request of the federation. This concerns mainly local institutions in the field of defense;

- Subsidies for economically weak provinces in addition to the inter-provincial system of financial equalization. The redistribution of taxes and inter-provincial financial equalization is carried out in several consecutive stages.

Within the frames of the horizontal equalization, different methods are used:

- Separation from the due provincial revenues of VAT of additional share for economically weak provinces;

- Equalizing subsidies for economically weak provinces at the expense of the economically strong provinces;

- additional subsidies from the federal funds for economically weak provinces.

In the horizontal distribution of the taxes, the following principle is valid: tax revenues belong to those provinces in which those taxes are collected by the local tax authorities. According to the distribution of the tax revenues, the primary financial potential of the individual provinces is determined, which serves as a starting point for their own horizontal financial equalization.

In order to ensure coverage of the costs in the economically weak provinces in accordance with the established constitutional principle of unity in the field of living throughout the country, the granting of subsidies to the economically weak provinces is provided, at the expense of the economically strong provinces. Here it is a question of equalization in terms of income, which does not take into account the specific financial needs of the individual provinces.

Determining the provinces, entitled to receive subsidies, and the provinces obliged to pay for them, is carried out based on a comparison of the financial potential of the provinces, including the incomes of municipalities (taxes, including the tax for earth development) and when taking into account some special factors (number of residents, additional maintenance costs of seaports, etc.). The obligation to provide additional subsidies or the right to receive them is determined by whether the financial potential of the individual provinces deviates from the average (for all provinces) financial potential.

The local budgetary-tax systems form the lower level (as a rule the third level in countries with a federal polity and second level in the unitary states) of the organizational system of budgetary relations, built throughout the country. The local budgetary-tax systems are "attached" to the territories of administrative units, which have a number of self-governing bodies in their basis. In the UK, there are such systems in the regions, counties and cities, in Germany - in the municipalities and cities, in France - in the departments and communes, in Japan - in the prefectures, regions and cities, in Italy and Belgium - in the provinces and communes, in the USA - in the regions, municipalities, special districts, etc.

The structure of the local budgetary-tax systems and their parameters in the different countries are, of course, different. This is conditioned by historical traditions, current legislation, dominating dimensions and forms of state control over local finances, statutory competence of local authorities, current relationships between local budgets and bank sector and other features. However, most of them have three supporting structures. These are in the first place the costs that the local authorities have in accordance with their established range of functions and tasks; in the second place: the income at the expense of which the funding of the operations of local government is provided; and the third place: the subsidies coming from higher budgets for the purpose of equalization of the financial capacity of the local territorial formations. These three structures connect the budgetary-tax systems in question with the regional ones, and we believe that the existence of such connection is the best testimony to the spread of federalism at all levels of the territorial organization of society.

According to the general rule, the volume of tasks solved by the holders of power and authority also determines the burden of its costs. The local budgets finance the costs for transport, water and gas, construction of schools, hospitals and other objects of social infrastructure, cover the cost of reconstruction of cities, development of roads, parks, utilities and housing. Furthermore, the local administrative authorities, police and courts are supported at the expense of the local budgets as well. In many cases, an expanding of the field of the so-called government under assignment is noted, when the federation and its entities assign 
the local administrations some of the tasks of the local government. In accordance with these processes, the costs of the local authorities increase rapidly.

Expenditure part of local budgets, in its intended function, is distributed for investments, current expenses and debt repayment. It would be simpler to consider the quantity of the costs of local budgets as a kind of indicator for the role of the local communities in the economic and social life of one country or another. The first group consists of Denmark, Norway and Sweden, where the cost of local budgets fluctuate within 20$30 \%$. The second group includes the countries in which the expenditures in local budgets fluctuate in the range 14-20\%. Here the Netherlands, England, Italy, Ireland are included. In the third group, these costs are below $10 \%$ of the GDP. In this group are Belgium, France, Spain and Portugal.

This classification indeed reflects to a certain extent the proportions, created in different countries in the division of power authorities, business and economic functions and, therefore, social roles between central government and local authorities. In addition, the greater relative amount of the costs of the authorities for local self-government is not equal to greater local freedom of action. Thus, in the Scandinavian countries, where this indicator is particularly high, there is also a firmer system of state regulation of the local costs and taxes. The local authorities here are under strong pressure from the central administration, which sets the framework and policy on spending the most important part of the local budgets - the costs of healthcare and education. Moreover, the central administration annually conducts negotiations with the associations to increase taxation, as a result of which a compromise solution that is suitable for both parties is reached.

In the other EU countries, the state also uses numerous and varied means to impact the policy of the local authorities, in particular by introducing mechanisms for the redistribution of financial resources between the different territorial units, and the level of this impact does not correspond at all to the size of financial resources of the authorities for local self-government. Moreover - in these countries, where an utmost importance of effective local self-government of the state is given, it is even imposed the duty (by the constitution and laws) of funding of the local authorities in accordance with their tasks, so that the costs of the local administrations to be guaranteed by the respective incomes.

The incomes of the local budgets consist of four major components: tax, non-tax income, subsidies and grants from higher budgets, loans. In previous periods, in many western countries there is an increase in the incomes of the local authorities. The most rapid increase is seen in the incomes of local taxation and subsidies from the state budget. In France, in particular, local tax revenues and subsidies in the period 19871990 grow by more than $4 \%$ a year. The revenues from other sources of income grow rapidly as well (for example in France with 3.3\% a year). In the UK and Denmark, where an extensive privatization of ownership and sale of real estate are conducted, the local authorities receive substantial financial support at the expense of those sources. An increase of the income part of the local budgets is also observed in Asia. For example, in Japan, the incomes of local authorities increase by $40 \%$ in 1990 , compared to 1985 , and compared to tax revenues - by $43 \%$.

In this period, the proportion of local taxes, state subsidies and other sources of income in the incomes of the local budgets of a number of countries is: in the USA - 65:23:12, in Japan - 42:40:28, in the FRG - 21:45:34, in France - 42:34:24, in Belgium - 36:54:10, in Denmark - 46:44:10.

We will consider in particular such an important source of income for local budgets, as tax revenues, the part of which differs more than 10 times in the specified budgets. In Italy, Ireland and the Netherlands, this part is the lowest and accounts for less than $10 \%$ of all resources of local budgets, as in Italy it is at a level of $7 \%$ in the provinces and $11 \%$ in the communes. In the Netherlands, it accounts for only $5 \%$.

The situation is different in countries such as Belgium, France, Germany, Denmark, UK, where incomes from local taxes exceed $20 \%$ of the budget incomes. In this group, the leaders are Denmark and France (over $40 \%$ ), followed by Belgium and the UK (just over $30 \%$ ). In Japan, revenues from local taxes are also an important part of local budgets, but are not dominating in them. This distinguishes the Japanese tax system from the US system, where local taxes often exceed $2 / 3$ of the municipal budget.

The formation of tax systems for each level is implemented in two ways. In the first place, the practice of bringing in own taxes, collected within an administrative unit, and their full inflow in the local budget under the control of local authorities, is widely spread: they can regulate independently or with certain restrictions the size of their taxes. The second direction is the division of the common taxes, the size of which is determined by the state and cannot be locally changed. These taxes are taken as additions of the nationwide taxes and the part of local collectives in tax revenues is defined as a certain percentage, depending on the amount of tax revenues calculated per capita. For example, in the FRG, under the law, a parallel collection of uniform tax at the level of federation and municipality is not allowed, i.e. only those taxes can be locally collected that have no federal analogue in the federal budget. In many countries, local taxes are calculated 
as additions to the taxes of the central government. Thus, in Italy part of the collected taxes of land tax and the agricultural tax also falls in the local budgets. In the USA, the FRG and France the local authorities are assigned to collect tax income (from physical and legal entities) and VAT (in the FRG and France), as in the provision of the collected amount to the state budget a certain percentage of the funds is locally kept and used to solve local problems.

Thus, the systems for local taxation in the western countries are quite different. Local taxes are generally numerous. For example, in Japan there are 30 local taxes, in Italy - over 30, in France - over 50, in Belgium around 100, in the UK the local budgets are funded at the expense of only two taxes.

The earlier income growth in the local budgets of the industrialized countries (except Germany) is namely related to the growth of revenues from local taxes flowing into central budgets. It is indicative that in many cases, the amounts of local taxes do not take into account the incomes of the taxpayers and tax-free threshold as a rule is not determined. Therefore, practically all residents are required to pay local taxes, even if their incomes are lower than the subsistence minimum. At the same time, as a rule, local authorities have no right to tax initiative, which is why all local taxes are approved by the central government.

With all the variety of systems for local taxation, a number of taxes that are collected in the majority of countries exist. These are income taxes (income tax from physical and legal entities in the USA, the FRG and France), personal tax (equal for all) in the UK, inheritance tax, taxes on property (property tax in the USA and Japan, land tax in the FRG, tax on land and buildings in France, craft tax in Germany), taxes relating to turnover (sales tax in the USA, VAT in France and Germany, excise duties on petrol, tobacco and alcoholic beverages), different types of duties and fees (for motor vehicles, parking, opening a restaurant, hunting, recreational events, dogs, for issuing various permit documents, etc.).

The basis for financial autonomy of local authorities lies in the property tax, collection and administration of the funds, which is exclusively conducted at a local level. The land and buildings (residential and industrial), as well as other kinds of immovable properties serve as objects for such taxation. The basis for taxation in almost all countries is the estimated value of the property. As far as the taxation and collection of property tax are in accordance with the decisions of the local authorities, the amount of the tax is determined both as a percentage of the value of the property, and as a fixed amount per a property unit. At the same time, in connection with the rare revaluation of the property (per 10 years on average) the property tax is not considered a flexible element of the locally conducted financial policy.

Of great importance to local authorities is also the sales tax. For example, in the USA this tax accounts for over $30 \%$ of all tax revenues in the local authorities. Collecting the tax is implemented at a state level and amounts to $3 \%-7 \%$, as thereafter the received funds are returned to the local authority in whose territory they are collected. Under the US legislation, subject to general sales tax is not only the total amount from the sale of each stage of the goods movement, but also the turnover from providing services to the population, which expands significantly the tax base of the states and municipalities, in terms of growth in the service sector.

The municipalities in the USA can introduce their own taxes on retail sales only if this is allowed by the state legislation. According to US economists, the unrestricted right of the local authority for seal-government to introduce sales tax may raise the issue of tax limits. In other words, if the municipality decides to introduce the tax in the city, and the county, in which the city is located, does not introduce such a tax, then the retailers can relocate their businesses outside the city to avoid the tax. Such situation can lead to urban sprawl and loss of income in local budgets, which is why the US experts suggest that it is more rational to introduce local sales taxes at a sub-federal level.

Another effective from our perspective method for state regulation of the implementation of social programs in the regions could be achieved through budgetary equalization. The financial resources of local territorial formations depend not only on their own tax revenues, but also on the system of equalization of their financial capabilities. It is about the already mentioned delivering of tax revenues in the higher budgets to local authorities. In many countries, the state subsidies and grants secure a significant part of the local budget income.

For example, in the USA the subsidies of the local authorities, coming from the budgets of the state, constitute $33 \%$ of their income, and the subsidies from the federal budget $-7 \%$. The state subsidies in the total amount of incomes of the municipalities in Germany account for $26 \%$. In France, the revenues from the central budget secure $30 \%$ of the income of the local authorities. 
State transfers in favor of local authorities are made through subsidies - grants for general purpose (e.g. in France subsidies for operation) and special targeted subsidies (subventions). In the USA, there are over 200 types of subsidies, in Italy more than 100, in the UK around 50.

The subsidies for general purpose (grants) are more suitable for local communities, seeking to fence themselves off from the pressure of the center and to preserve its autonomy. They are provided as a rule to cover local budget deficit and contain fewer restrictions on their use. Such system can be seen in France and the UK. It is also used in Belgium, the Netherlands, Germany, the Scandinavian countries. In the unitary states, the subsidies are provided by the central government, in the federal states - by both the federal government and the entities of the federation. The subsidies for general purpose serve as compensation for the lack of tax revenues.

The "targeted subsidies" are oriented not only according to the level of incomes, but also according to the special purposes for which they are provided. In the first place, they are acting as means for government regulation, in order to stimulate certain investments in certain locations. In many countries (e.g. in Germany), the provision of such resources is conditioned by participation of the local authorities in the financing as well. As a result, extra budgetary investments, as well as the related to the subsidies obligations arise. In connection with the tasks and objectives set, a more or less accurate account of the costs and then a financial statement are necessary when using the subsidies. Therefore, it is widely believed that the range of actions of the local authorities is rather narrowed, than serving them for financial support.

The targeted subsidies are typical example of the Scandinavian countries, where they are intended for implementation of programs in the sectors of education and health care. They can be seen in the USA, Japan, Italy, where they are used to fund police, correctional institutions, economic and social infrastructure. In Germany, the targeted subsidies are used mainly for capital investments. The resources for them are reserved in a special fund at a provincial level, formed at the expense of a certain part of deductions from the general taxes due to the provinces, as well as from the proceeds from own taxes.

Another means are non-tax revenues. A significantly small role in the local budgets of the western countries is played by the non-tax revenues, including income from locally owned properties, utilities, business, fines, sales of property, cash, etc. Revenues in local budgets, coming from this item, fluctuate within the range of $10-25 \%$ on average. Income level of local ownership also varies by country and is related to its size and the specifics of the local utility companies. In the last two decades, a trend of growth in non-tax revenues is noticed. It is caused by both the utility prices growth and the reforms on decentralization of state government, which have led to the expansion of economic and business autonomy of local authorities. The policy on privatization of state property at a local level also helps to increase the non-tax revenues (for example in the UK and Denmark). As a rule, however, these are one-time increases, which have not caused significant changes in the existing proportions.

For the purposes of state regulation of social programs, both regional and local loans can be used. Regional and local loans are a recognized mechanism for territorial development in many countries with a market economy. Securities, issued by local authorities, occupy a prominent position in the structure of the stock exchanges of these countries. Many types of securities exist dozens of years and are considered reliable financial instruments for investment of funds, and are traditionally subject to investment interest from pension or mutual funds, entrepreneurs and population. Highly developed are the markets for regional and municipal securities in the USA, Germany, the UK and other European countries, as well as in a number of Latin American countries (Terziev, 2018-d; Terziev, Georgiev, 2018e-f; Terziev, Arabska, 2014; Terziev, 2015-b; Terziev, Arabska, 2016a).

\section{CONCLUSION}

The problems of the regulation of social development are subject to increasing interest in the field of research, policy discussions and management practice. They become especially topical in the years of transition and the membership of Bulgaria in the European Union, as well as the emerging new challenges facing Bulgaria in the new demographic, economic and social conditions (Terziev, 2015-b).

\section{REFERENCE LIST}

Georgiev, Marin. (2016). Obshtestvenoto i ikonomichesko razvitie v konteksta na sotsialnite politiki. // 
Spisanie za nauka „Novo znanie“. Visshe Uchilishte po Agrobiznes i Razvitie na Regionite, 5, 2016, N 4, str. 26-41, ISSN 2367-4598 (Online), (Print) ISSN 1314-5703 (Георгиев, Марин. Общественото и икономическо развитие в контекста на социалните политики. // Списание за наука „Ново знание“. Висше училище по агробизнес и развитие на регионите, 5, 2016, N 4, стр. 26-41, ISSN 2367-4598 (Online), (Print) ISSN 1314-5703.

Georgiev, Marin. (2017). Sbalansirovannaya karta kak alyternativa malogo biznesa. // Innovatsionnie tehnologii v nauke novogo vrmeni, Sbornik statey Mezhdunarodnoy nauchno - prakticheskoy konferentsii 1 fevralya 2017 g., Ufa NITS AETERNA, Chasty 1, 2017, s. 43-49, ISBN 978-5-00109004-5, ISBN 978-5-00109-007-6 (Георгиев, Марин. Сбалансированная карта как альтернатива малого бизнеса. // Инновационніе технологии в науке нового врмени, Сборник статей Международной научно - практической конференции 1 февраля 2017 г., Уфра НИЦ АЭТЕРНА, Часть 1, 2017, с. 43-49, ISBN 978-5-00109-004-5, ISBN 978-5-00109-007-6).

Georgiev, Marin. (2017a). Impacts of active social programs on labor market. // Mezhdunarodnayy nauchnayy zhurnal «Innovatsionnaya nauka». NITS Aeterna, N 02-1, 2017, pp. 139-143, ISSN 24106070 (Georgiev, Marin. Impacts of active social programs on labor market. // Международный научный журнал «Инновационная наука». НИЦ Аэтерна, N 02-1, 2017, pp. 139-143, ISSN 24106070).

Terziev, V., Kanev, D. (2019). Modern developments in behavioral economics. // Smart Technologies and Innovations in Design for Control of Technological Processes and Objects: Economy and Production Proceeding of the International Science and Technology Conference "FarEastCon-2018" Volume 138, October 2-4, 2018, Vladivostok, Russian Federation, pp. 10-23, 2019, (Print) ISBN978-3-030-15576-6, (Online) ISBN978-3-030-15577-3.

Terziev, Venelin. (2019a). Provision of integrated employment and social assistance services in Bulgaria. // Smart Technologies and Innovations in Design for Control of Technological Processes and Objects: Economy and Production Proceeding of the International Science and Technology Conference "FarEastCon-2018" Volume 138, October 2-4, 2018, Vladivostok, Russian Federation, pp. 24-39, 2019, (Print) ISBN978-3-030-15576-6, (Online) ISBN978-3-030-15577-3.

Terziev, Venelin. (2019b). Problems of control in the social sphere. // INTCESS 2019- $6^{\text {th }}$ International Conference on Education and Social Sciences, 4-6 February, 2019, Dubai, International Organization Center of Academic Research, Istanbul, Turkey, pp. 577-593, ISBN: 978-605-82433-5-4.

Terziev, Venelin. (2019c). The criterion "competence" in the economic sector. // INTCESS 2019- $6^{\text {th }}$ International Conference on Education and Social Sciences, 4-6 February, 2019, Dubai, International Organization Center of Academic Research, Istanbul, Turkey, pp. 1241-1247, ISBN: 978-605-824335-4.

Terziev, Venelin. (2019d). Social policy and labor market development in Bulgarian transition period. // INTCESS 2019- $6^{\text {th }}$ International Conference on Education and Social Sciences, 4-6 February, 2019, Dubai, International Organization Center of Academic Research, Istanbul, Turkey, pp. 703-714, ISBN: 978-605-82433-5-4.

Terziev, Venelin. (2019e). Theoretical basis of development of labor market and social policy in the republic of Bulgaria. // INTCESS 2019- ${ }^{\text {th }}$ International Conference on Education and Social Sciences, 4-6 February, 2019, Dubai, International Organization Center of Academic Research, Istanbul, Turkey, pp. 715-726, ISBN: 978-605-82433-5-4.

Terziev, Venelin. (2019f). The problem of social efficiency- Indicators for social efficiency. // INTCESS 2019$6^{\text {th }}$ International Conference on Education and Social Sciences, 4-6 February, 2019, Dubai, International Organization Center of Academic Research, Istanbul, Turkey, pp. 669-678, ISBN: 978605-82433-5-4.

Terziev, Venelin. (2019g). Experiencing social policy development and efficiency measurment. // INTCESS 2019- 6th International Conference on Education and Social Sciences, 4-6 February, 2019, Dubai, International Organization Center of Academic Research, Istanbul, Turkey, pp. 679-686, ISBN: 978605-82433-5-4.

Terziev, Venelin. (2019h). Efficiency and assessment of social technology. // INTCESS 2019-6th International Conference on Education and Social Sciences, 4-6 February, 2019, Dubai, International Organization Center of Academic Research, Istanbul, Turkey, pp. 687-694, ISBN: 978-605-82433-5-4.

Terziev, Venelin. (2019i). Conceptual framework of social adaptation. // INTCESS 2019- $6^{\text {th }}$ International 
Conference on Education and Social Sciences, 4-6 February, 2019, Dubai, International Organization Center of Academic Research, Istanbul, Turkey, pp. 494-503, ISBN: 978-605-82433-5-4.

Terziev, Venelin. (2019j). The dependence social adaptation- socialization. // INTCESS 2019- $6^{\text {th }}$ International Conference on Education and Social Sciences, 4-6 February, 2019, Dubai, International Organization Center of Academic Research, Istanbul, Turkey, pp. 478-485, ISBN: 978-605-82433-5-4.

Terziev, Venelin. (2019k). Social activity and human resources as social development factors. // INTCESS 2019- $6^{\text {th }}$ International Conference on Education and Social Sciences, 4-6 February, 2019, Dubai, International Organization Center of Academic Research, Istanbul, Turkey, pp. 546-553, ISBN: 978605-82433-5-4.

Terziev, Venelin. (2018). The active model of a social programme and its strategic advantage // ADVED 2018- $4^{\text {th }}$ International Conference on Advances in Education and Social Sciences Abstracts \& Proceedings, 15-17 October 2018- Istanbul, Turkey, International Organization Center of Academic Research, www.ocerints.org, Istanbul, Turkey, 2018, pp. 189-203, ISBN: 978-605-82433-4-7.

Terziev, Venelin. (2018a). Active social programs development in Bulgaria: contemporary challenges and social management instruments. // ADVED 2018- $4^{\text {th }}$ International Conference on Advances in Education and Social Sciences Abstracts \& Proceedings, 15-17 October 2018- Istanbul, Turkey, International Organization Center of Academic Research, www.ocerints.org, Istanbul, Turkey, 2018, pp. 149-163, ISBN: 978-605-82433-4-7.

Terziev, Venelin. (2018b). Social assistance services and integrated employment in Bulgaria. // ADVED 2018- $4^{\text {th }}$ International Conference on Advances in Education and Social Sciences Abstracts \& Proceedings, 15-17 October 2018- Istanbul, Turkey, International Organization Center of Academic Research, www.ocerints.org, Istanbul, Turkey, 2018, pp. 164-177, ISBN: 978-605-82433-4-7.

Terziev, Venelin. (2018c). Impact of the labor market policies for ensuring employment. // ADVED 2018- $4^{\text {th }}$ International Conference on Advances in Education and Social Sciences Abstracts \& Proceedings, 1517 October 2018- Istanbul, Turkey, International Organization Center of Academic Research, www.ocerints.org, Istanbul, Turkey, 2018, pp. 178-188, ISBN: 978-605-82433-4-7.

Terziev, Venelin. (2018d). Importance of human resources to social development. // ADVED 2018- $4^{\text {th }}$ International Conference on Advances in Education and Social Sciences Abstracts \& Proceedings, 1517 October 2018- Istanbul, Turkey, International Organization Center of Academic Research, www.ocerints.org, Istanbul, Turkey, 2018, pp. 204-212, ISBN: 978-605-82433-4-7.

Terziev, V., Georgiev, M. (2018e). A strategic framework for the development of social entrepreneurship in Bulgaria. // Knowledge - International Journal, August 2018, Institute of Knowledge Management, Skopje, Macedonia, 25, 2018, N 1, pp. 23-34, ISSN 1857-923X (for e-version), ISSN 2545 - 4439 (for printed version).

Terziev, V., Georgiev, M. (2018f). Support for the development of social entrepreneurship in Bulgaria. // Knowledge - International Journal, September, 2018, Institute of Knowledge Management, Skopje, Macedonia, 26, 2018, N1, pp.57-74, ISSN 1857-923X (for e-version), ISSN 2545 - 4439 (for printed version).

Terziev, V., E., Arabska. (2014). Assessment of active social policies' impacts on labor market in the Republic of Bulgaria. Kolektivnaya monografiya "Sotsialyno-ekonomicheskie i pravovay razvitiya ekonomiki“, Ufa, Aeterna. Rossiya, 2014. ISBN 978-5-906769-97-8, str. 3-57 (Terziev, V., E. Arabska. (2014). Assessment of active social policies' impacts on labor market in the Republic of Bulgaria. Колективная монография „Социально-экономические и правовы развития экономики“, Уфа, Аэтерна. Россия, 2014. ISBN 978-5-906769-97-8, стр. 3-57).

Terziev, Venelin. (2015). Impact of active social policies and programs in the period of active economic transformations in Bulgaria, „East West” Association for Advanced Studies and Higher Education, Vienna, 2015, ISBN 78-3-903063-44-0, 434 p.

Terziev, Venelin. (2015a). Assessment of active social policies impact of social policies on transformation processes in bulgarian economy, Moscow, 2015, Publisher „Перо“, 110 p.

Terziev, Venelin. (2015b). Opportunities for improving the efficiency of the social adaptation of servicemen discharged from military service in Bulgaria:- Novosibirsk: Publisher CRNS, 2015. ISBN 978-5-00068402-3, 270 p.

Terziev, V., E., Arabska. (2016a). Effektivnoe vliyanie na raynok truda posredstvom uluchsheniya realizatsii 
sotsialynoy politiki. Novosibirsk: Izdatelystvo TSRNS, 2016. ISBN 978-5-00068-496-2, $312 \mathrm{str}$ (Терзиев, В., Е. Арабска. (2016а). Эфрфективное влияние на рынок труда посредством улучшения реализации социальной политики. Новосибирск: Издательство ЦРНС, 2016. ISBN 978-5-00068-496-2, 312 стр). 